Article

\title{
Communities and Attachment Networks Associated with Primary, Secondary and Alternative Foundation Species; A Case Study of Stressed and Disturbed Stands of Southern Bull Kelp
}

\author{
Mads S. Thomsen ${ }^{1,2, *(1)}$ and Paul M. South ${ }^{3}(\mathbb{D}$ \\ 1 Centre for Integrative Ecology; Marine Ecology Research Group, School of Biological Sciences, \\ University of Canterbury, Private Bag 4800, Christchurch 8140, New Zealand \\ 2 UWA Oceans Institute and School of Plant Biology, University of Western Australia, Hackett Drive, \\ Crawley 6009, WA, Australia \\ 3 Cawthron Institute, 98 Halifax Street East, Nelson 7010, New Zealand; paul.martin.south@gmail.com \\ * Correspondence: mads.solgaard.thomsen@gmail.com
}

Received: 13 March 2019; Accepted: 3 April 2019; Published: 10 April 2019

\begin{abstract}
Southern bull kelps (Durvillaea spp., Fucales) are 'primary' foundation species that control community structures and ecosystem functions on temperate wave-exposed rocky reefs. However, these large foundation species are threatened by disturbances and stressors, including invasive species, sedimentation and heatwaves. It is unknown whether 'alternative' foundation species can replace lost southern bull kelps and its associated communities and networks. We compared community structure (by quantifying abundances of different species) and attachment-interaction networks (by quantifying which species were attached to other species) among plots dominated by Durvillaea spp. and plots where Durvillaea spp. were lost either through long-term repeated experimental removals or by recent stress from a marine heatwave. Long-term experimental removal plots were dominated by 'alternative' foundation species, the canopy-forming Cystophora spp. (Fucales), whereas the recent heatwave stressed plots were dominated by the invasive kelp Undaria pinnatifida (Laminariales). A network analysis of attachment interactions showed that communities differed among plots dominated by either Durvillaea spp., Cystophora spp. or U. pinnatifida, with different relationships between the primary, or alternative, foundation species and attached epiphytic 'secondary' foundation species. For example, native Cystophora spp. were more important as hosts for secondary foundation species compared to Durvillaea spp. and U. pinnatifida. Instead, Durvillaea spp. facilitated encrusting algae, which in turn provided habitat for gastropods. We conclude that (a) repeated disturbances and strong stressors can reveal ecological differences between primary and alternative foundation species, (b) analyses of abundances and attachment-networks are supplementary methods to identify linkages between primary, alternative and secondary foundation species, and (c) interspersed habitats dominated by different types of foundation species increase system-level biodiversity by supporting different species-abundance patterns and species-attachment networks.
\end{abstract}

Keywords: Network analysis; community analysis; epibiosis; habitat cascades; facilitation cascade; foundation species; biodiversity; marine heatwave

\section{Introduction}

\subsection{Primary, Secondary and Alternative Foundation Species}

Some species are ecologically more important than others in controlling species-interactions, ecosystem functions, community structures and biogeochemical cycling [1-9]. Typically, these ecologically 
important 'foundation species' are large, abundant, and long-lived species that dominate and define habitats and have significant per capita effects on other organisms and ecosystem functions $[10,11]$. Ecologists have traditionally studied the ecological importance of foundation species by combining species abundance data with species removal or addition-experiments to quantify per capita effects [12-17]. These classical methods can be supplemented with network analyses to identify how foundation species may modify networks of different types of ecological interactions [18,19]. Most network analyses in ecology have focused on trophic species interactions [20] or mutualistic pollination and seed dispersal webs in terrestrial systems [21], and with marine examples for fish, sea anemones and shrimps [22-25]. Many studies have also analysed bipartite attachment networks between trees and epiphytes [26-34]. Similar host-epiphyte interactions are prevalent in marine ecosystems $[9,13,14,35]$, but we are not aware of studies that have analysed these attachment-interactions with community-wide network metrics.

Large host organisms, such as trees, corals and canopy-forming macroalgae (seaweeds), are sometimes considered 'primary' (or basal) foundation species because they control biodiversity and abiotic conditions, and can provide attachment space for epiphytes [13]. However, the epiphytes themselves can also be foundation species when and where they increase biodiversity and alter species interactions [36-40]. Epiphytes can therefore sometimes be considered 'secondary' (or intermediate) foundation species, because their 'foundation-species-effect' requires the presence of the primary foundation species [13,41-45]. Host-epiphyte studies emphasise that foundation species can co-exist in a hierarchy of structural dependencies, thereby increasing biodiversity through facilitation and habitat cascades [41,44]. More recently, it has been shown that longer chains of structural dependencies can occur with co-existing primary (e.g., cockles or clams), secondary (e.g., seaweed or barnacles), tertiary (e.g., snails or tunicates) and higher order (e.g., bryozoans and other seaweeds) foundation species, resulting in long habitat cascades $[14,46]$. However, past studies have only (a) documented interactions between a few species from a larger community, (b) emphasised 'linear' chains of interactions, and (c) have not been analysed in a framework of community-wide network metrics.

Primary foundation species, such as trees and canopy-forming macroalgae, are critical for maintaining ecosystem functions and services but are threatened by anthropogenic activities, such as habitat alterations, climate change, resource extraction, pollution and invasive species $[15,47,48]$. However, in many cases, when primary foundation species are lost because of human activities, other biological organisms, such as fast-growing shrubs [49], non-native marsh plants [50,51], or turfing or invasive macroalgae [52-54] can colonise the vacated areas. These new dominant species can also be large organisms that can control biodiversity and modify abiotic conditions and could possibly replace many ecosystem functions and services. Here, we refer to these new large and dominant species as 'alternative foundation species', because their foundation-species-effects only effectuate after the primary foundation species has been lost due to physical disturbances or physiological stressors. Here, physical disturbances are processes that cause the instantaneous removal of biomass, such as when storms dislodge individuals or herbivorous fish take bites out of kelp fronds. By comparison, stress effects reflect slower processes that limit physiological performance. For example, heat stress can increase respiration, promote heat stress proteins, increase susceptibility to diseases, and can eventually lead to death [55-57]. The replacement of primary foundation species with alternative foundation species mirrors switches between alternative stable states [58,59], except that the alternative foundation species here become dominant if the primary foundation species is increasingly (not randomly) stressed or disturbed. In this context, alternative foundations species are 'passengers' or 'back-seat drivers' of ecological change, rather than their direct drivers [60-63].

\subsection{Disturbances and Stress to Southern Bull Kelps}

Large and long-lived canopy-forming macroalgae such as fucoids and kelps are typical foundation species because they control biodiversity, abiotic conditions, and ecosystem functions through habitat formation, shading and whiplash, high primary productivity and nursery provisioning [64-70]. 
However, fucoids and kelps are threatened by climate change, marine heatwaves, acidification, invasive species, increased turbidity, and sediment smothering [53,71-74]. It is therefore critical for ecologists and managers to understand how systems dominated by these macroalgae may change when they are exposed to stressors and disturbances.

In New Zealand, wave-exposed rocky shores are often dominated by the southern bull kelps, Durvillaea poha, D. antarctica and D. willana (hereafter 'Durvillaea spp.'). These fucoid species are some of the world's largest macroalgae; they can live up to 10 years, grow to $10 \mathrm{~m}$ in length and weigh up to $70 \mathrm{~kg}$ per individual $[70,75,76]$. Southern bull kelps are classic primary foundation species because their large, heavy fronds control community structures through whiplash and shading, and their complex perennial holdfast provides biogenic habitats to highly diverse invertebrate communities [68,70,75-78]. However, although the ecology of southern bull kelps as a primary foundation species has been studied in detail (see [79] and references therein), and diebacks following seismic uplifts, marine heatwaves and storms have been described [52,80-82], it is unknown whether any alternative foundation species replace lost Durvillaea spp.

The aim of our study was to identify primary, alternative and secondary foundation species in intertidal stands of southern bull kelp exposed to repeated experimental disturbances (since 2012) or heatwave-induced stress (since 2017). Today, these stands are dominated by either Durvillaea spp. (primary foundation species) or other large canopy-forming macroalgae (alternative foundation species, the native fucoids Cystophora spp., or the invasive laminarialean kelp Undaria pinnatifida) and smaller epiphytes (secondary foundation species). We hypothesise that (i) southern bull kelps are the primary foundation species because they directly control biodiversity, abundances of alternative and secondary foundation species, and attachment-networks, and (ii) where southern bull kelps have been lost, other canopy-forming macroalgae can become alternative foundation species, resulting in different sets of associated species and attachment-networks.

\section{Methods}

\subsection{Study Site, Model Organisms, Experimental Conditions and Data Clustering}

This study was done on the Moeraki Peninsula ( $\left.45^{\circ} 25^{\prime} \mathrm{S}, 170^{\circ} 51^{\prime} \mathrm{E}\right)$ in south-eastern New Zealand. The peninsula comprises semi-exposed limestone and conglomerate rock platforms. The low intertidal zone is dominated by Durvillaea poha, D. antarctica and D. willana and is occupied by at least seven other fucalean species, including three species of Cystophora (C. retroflexa, C. scalaris, C. torulosa), and the invasive kelp, Undaria pinnatifida.

We assessed species-abundances and host-epiphyte attachments in plots dominated by either Durvillaea spp., Cystophora spp. or $U$. pinnatifida that had arisen through experimental removals or climatic events over the preceding 6 years. Here, Durvillaea spp. were considered to be the primary foundation species, whereas Cystophora spp. and $U$. pinnatifida were considered to be alternative foundation species because they only colonised plots in the absence of Durvillaea spp. (see introduction for more detail). In 2012, we established 20 plots of $1 \mathrm{~m}^{2}$ in size in healthy and extensive southern bull kelp forests (all plots had 100\% cover) in the low intertidal zone. Ten of the plots were randomly assigned to a repeated removal treatment in which we removed all Durvillaea spp. including their holdfasts, recruits and all overhanging blades from all adjacent areas. The repeated removal was maintained by removing Durvillaea spp. recruits and re-growing neighbouring southern bull kelp blades at least twice a year, until the plots were monitored in September 2018. All our removal plots were free of whiplash and shading effects from southern bull kelp throughout the experiment. The remaining 10 plots were left as un-manipulated controls but the extreme hot summer of 2017-2018 reduced canopy cover of Durvillaea spp. in Moeraki [52] and caused 100\% canopy loss in four of the 10 undisturbed control plots. Therefore, in 2018 we also sampled 10 interspersed unmarked full-canopy Durvillaea spp. plots that had survived the heatwave (see section on study limitation in the discussion for details), which, given the size and longevity of individuals within these plots, were most likely southern bull kelp habitat in 2012 when the original plots were established. Data from the 30 plots 
sampled in 2018 were re-classified into three types of habitats that were either dominated by Durvillaea spp. $(n=16)$, Cystophora spp. $(n=7)$, or U. pinnatifida $(n=7)$. All plots dominated by Cystophora spp. arose following the long-term repeated removals, whereas the $U$. pinnatifida dominated plots comprised three plots where southern bull kelp was lost from repeated removals and the four plots where southern bull kelp was lost following the hot summer of 2017/18.

Abundances of macroscopic taxa $(>5 \mathrm{~mm})$ were quantified in situ in $0.5 \times 0.5 \mathrm{~m}$ quadrats placed haphazardly near the centre of each plot during low tide. All plots were separated by more than $1 \mathrm{~m}$ horizontally (typically 5-10 m) and had less than $0.3 \mathrm{~m}$ vertical differences (mean, SE, maximum and minimum elevation of 20 plots, measured with a Trimble RTK GPS $=-0.60,0.02,-0.93$ and $-0.76 \mathrm{~m}$ above mean low water). Abundances were quantified by estimating percent cover of sessile taxa and counting mobile taxa in $0.5 \times 0.5 \mathrm{~m}$ quadrats divided into 100 cells. Attachments were quantified in $0.25 \times 0.25 \mathrm{~m}$ quadrats by recording all species-combinations of plants and animals (epibionts) attached to biogenic hosts (including dead shells). For example, coralline turf attached to the snail Lunella smaragda, L. smaragda attached to another L. smaragda, and L. smaragda attached to coralline turf represent three different attachment-interactions. Note that mobile animals were considered 'attached' to the host on which they were observed, although mobile species can move among hosts. Note also that we did not remove any algal material, including holdfasts, thereby excluding very small and/or cryptic taxa hiding underneath and within these complex biogenic habitats from our analysis. Most taxa were identified to the species level, except for sponges, encrusting and turfing coralline algae, and small cryptic filamentous algae that were identified to coarser taxonomic groups. Sampling was carried out over five consecutive day-time low tides. However, because abundances and attachments were quantified at different low tides using different sized quadrats that were placed haphazardly around the plot centre, the two data sets do not align in a complete one-to-one match.

The network analysis was done as a single community analysis that included both sessile and mobile species (i.e., sessile species were recorded attached to mobile species and vice versa). We therefore also standardised abundances of mobile vs. sessile taxa into a single community analysis [83]. Specifically, the abundances of mobile and sessile species were standardised by dividing a species' abundance in a quadrat with the summed abundance of either all sessile or all mobile organisms enumerated in the 30 sampled quadrats. This standardization method preserves the dominance patterns among species across all the samples for both sessile and mobile taxonomic groups, and only relies on the supposition that mobile organisms are of equal importance to sessile organisms. We included the measured abundances and attachment-interactions of Durvillaea spp., Cystophora spp. and U. pinnatifida in statistical analyses because (a) the data were mensurative (we did not control heatwave stress or the colonization of Cystophora spp. and $U$. pinnatifida), and (b) we compared habitats dominated by different types of foundation species where the attributes of the foundation species themselves have ecological relevance [84-87]. This is a relatively common analytical approach (particularly in mensurative studies) when the test object of interest (i.e., the foundation species) can be an integrated part of the response [see 84 for a detailed discussion].

\subsection{Analyses of Community Structures From Abundance Data}

First, we tested whether diversity, community structure, and abundances of common taxa varied among the three habitats types (i.e., plots dominated by Durvillaea spp., Cystophora spp. or U. pinnatifida). Three univariate diversity metrics (richness, evenness and Shannon's diversity) were calculated for each plot and used to analyse the effect of habitat type with single factor analyses of variance (ANOVA; variances were homogeneous: $p>0.05$ in Levine's test). Significant analyses were followed by post hoc Student-Newman-Keuls (SNK) tests to identify differences among the treatments. Multivariate community structure was analysed with Analysis of Similarities (ANOSIM) using the Bray Curtis dissimilarity index derived from square root transformed cover-data to downplay the importance of the most abundant taxa. The results were visualised with a multidimensional scaling plot (MDS) with vector overlays (calculated from Pearson's ranked correlation coefficients) of the taxa that contributed to $50 \%$ 
of the total multivariate structure. Finally, the similarity of percentages (SIMPER) routine was used to identify taxa that represented $90 \%$ of the community structure for each of the three habitats. Abundances of all these taxa were compared visually with means plus standard error graphs.

\subsection{Analyses of Community Structures From Attachment Data}

Network metrics were calculated and analysed to examine whether diversity and community structure varied among the three types of habitats based on attachment data. Again, three univariate metrics (betweenness centrality, average neighbour degrees and total degrees, see online supplement for descriptions) were calculated for each plot and the effect of habitat was analysed with single factor ANOVAs (variances were homogeneous: $p>0.05$ in Levine's test) followed by post hoc SNK tests to identify significant differences among treatments. These metrics were calculated per plot allowing us to calculate means and standard errors, and test for effects between treatments with different sample sizes [19]. We analysed for multivariate community structure with ANOSIM on the total number of links for each species in the assemblage (the only significant univariate network metric - see results). Multivariate data were square root transformed prior to analysis to downplay the importance of the most connected taxa. Analyses were done using the Bray Curtis dissimilarity index and visualised with an MDS plot with vector overlays of the taxa that contributed to $50 \%$ of the total multivariate structure. We also identified the most connected taxa (with $>3$ in- or out-going links) and visualised the mean density (+SE) of links per plot for each of the three habitats. For this analysis, in- and out-going links were analysed separately to identify important hosts (= outgoing links) and attached plants and animals (= ingoing links). Finally, all attachment interactions within and among the three habitats were visualised with standard network plots to highlight the position of mobile and sessile species in these networks. Note that the full Durvillaea spp. network could include more interactions compared to the Cystophora spp. and U. pinnatifida networks, simply because it is derived from a larger sample size [19,88].

All univariate diversity metrics, ANOSIM, SIMPER and MDS plots were calculated, analysed and produced in Primer [89], ANOVA and Student-Newman-Keuls tests were analysed in Unistat [90], and network metrics and network graphs calculated and plotted in Polinode [91].

\section{Results}

\subsection{Abundances}

There were no effects on richness (Figure $1 \mathrm{~A}, \mathrm{~F}_{2,29}=0.127, p=0.881$ ), Shannon diversity (Figure 1B, $\mathrm{F}_{2,29}=1.337, p=0.278$ ), or evenness (Figure $1 \mathrm{C}, \mathrm{F}_{2,29}=2.615, p=0.091$ ) between plots dominated by primary or alternative foundations species. However, multivariate assemblage structures were significantly different among the three habitat types (Figure $2 \mathrm{~A}, \mathrm{R}_{\text {global }}=0.78, p=0.1 \%$; $p$ for all pairwise comparisons $<0.4 \%$ ). The Durvillaea spp. habitat was dominated by the Durvillaea spp. themselves and encrusting coralline algae that correlated positively with the abundance of the diminutive $(<5 \mathrm{~mm})$ turf-forming red algae Gelidium microphyllum (Figures 2A and 3A). In plots where Undaria pinnatifida was dominant, coralline turf was abundant and there were positive correlations with the gastropod L. smaragda and the brown turfing alga Halopteris congesta. Finally, in the plots dominated by Cystophora spp., coralline turf was again abundant and positively correlated with the abundance of several red algae including Jania sphaeroramosa and Lophothamnion hirtum as well as the snails Cantharidella spp. (Figures 2A and 3A).

\subsection{Attachments}

There were no effects of habitat among those dominated by either primary or alternative foundations species on betweenness centrality (Figure 1D, $\mathrm{F}_{2,29}=0.332, p=0.720$ ) or neighbour degrees (Figure $1 \mathrm{E}, \mathrm{F}_{2,29}=0.268, p=0.767$ ). However, total degrees were significantly greater in plots dominated by Cystophora spp. compared to plots dominated by Durvillaea spp. or U. pinnatifida (Figure 1F, $\mathrm{F}_{2,29}=5.145, p=0.013$ ). In addition, multivariate assemblages were significantly different among all three habitats dominated by either primary or alternative foundations species (Figure $2 B, R_{\text {global }}=0.361$, 
$p=0.1 \%$; $p$ for all pairwise comparisons $<3.5 \%$ ). Vector overlays (Figure $2 \mathrm{~B}$ ) showed that attachment interactions of encrusting corallines, Chaetomorpha coliformis, Callophyllis calibletharoides, Ballia hirsuta and Notoacmea spp. correlated positively with plots dominated by Durvillaea spp. By comparison, C. torulosa, C. scalaris, coralline turf, J. sphaeroramosa, Heterosiphonia sp. and L, hirtum were positively correlated with plots dominated by Cystophora spp., with a mixture of similar species correlating positively with plots dominated by U. pinnatifida (Figure 2B).

The most common outgoing links (hosts) in plots dominated by Cystophora spp. were C. scalaris, C. retroflexa, coralline turf and J. sphaeroramosa (Figure 3B). By comparison, plots dominated by Durvillaea spp. had fewer host species that were represented by small macroalgae like B. hirsuta, the abalone Haliotis australis and coralline turf. Plots dominated by $U$. pinnatifida, had a mixture of common host species that included coralline turf, encrusting corallines, Cystophora spp. and H. congesta. In contrast to Cystophora spp., neither Durvillaea spp. nor U. pinnatifida were themselves recorded as host species in any of the 16 Durvillaea spp. or 7 U. pinnatifida plots (Figure 3B).

The number of (attached) ingoing links were also higher in plots dominated by Cystophora spp. compared to plots dominated by Durvillaea spp. or U. pinnatifida (Figure 3C). Common attached species in the Cystophora spp. plots included J. sphaeroramosa, L. hirtum, Micrelenchus spp., Cantharidella spp., Dipterosiphonia heteroclada, Ceramium spp., Cricophorus nutrix, Heterosiphonia sp. and an unidentified diminutive red alga. By comparison, U. pinnatifida had intermediate, and Durvillaea spp. low numbers of ingoing links, characterised by small macroalgae (C. coliformis, C. calibletharoides and Anotrichium crinitum) and the diminutive limpet Notoacmea spp. (Figure 3C).
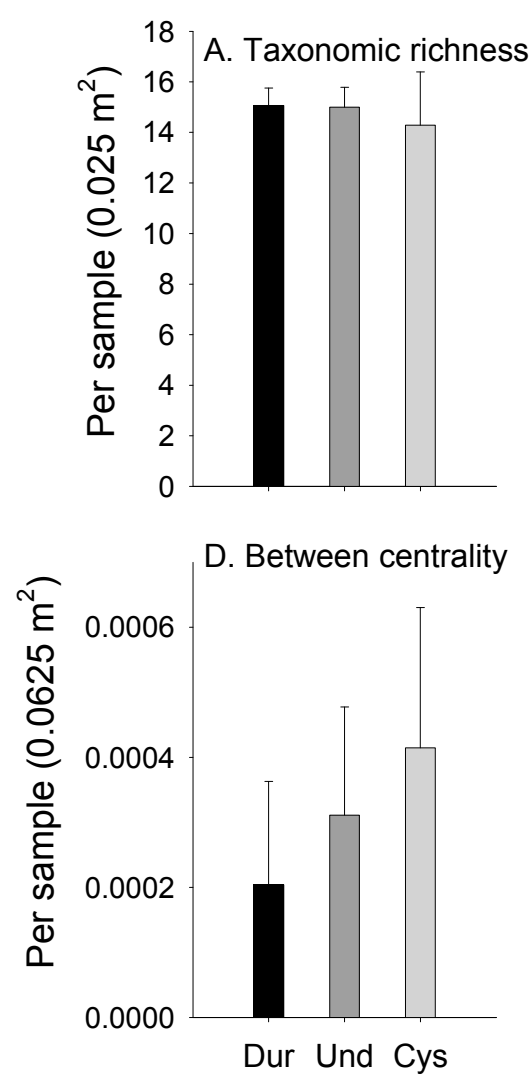
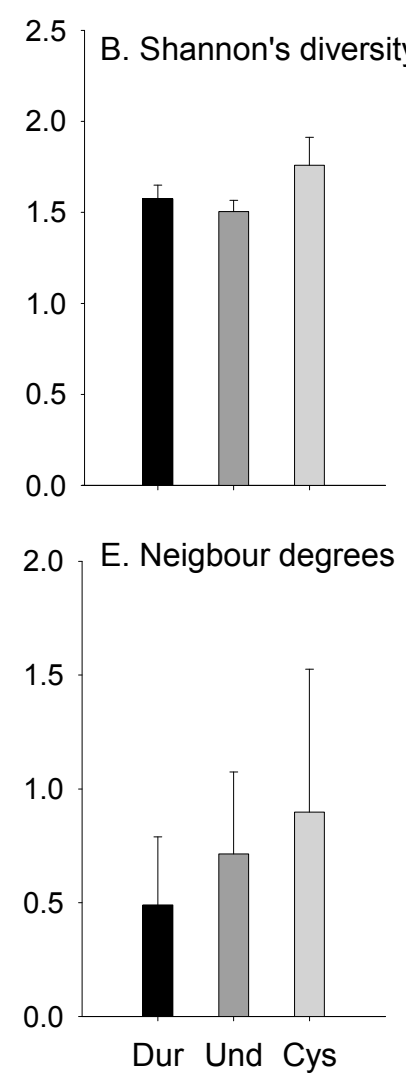
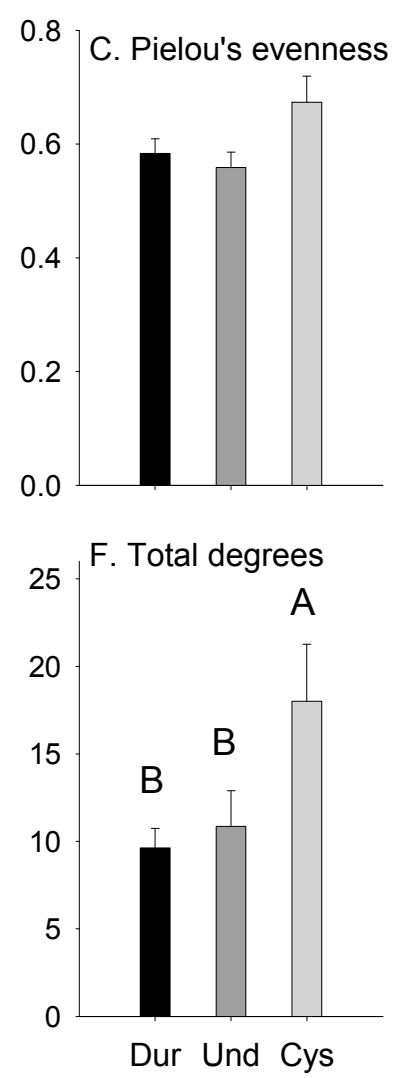

Figure 1. Mean (+SE) Taxonomic richness (A), Shannon's diversity (B), Pielou's evenness (C), Betweenness centrality (D), average Neighbour degrees $(\mathbf{E})$, and Total degrees $(\mathbf{F})$ in plots dominated by Durvillaea spp. (Dur, $n=16$ ), Undaria pinnatifida (Und, $n=7$ ) or Cystophora spp. (Cys, $n=7$ ) in September 2018 (all 30 plots were Durvillaea spp. habitats in 2012). Plot A-C were calculated from abundance data and plot D-E from attachment data. 


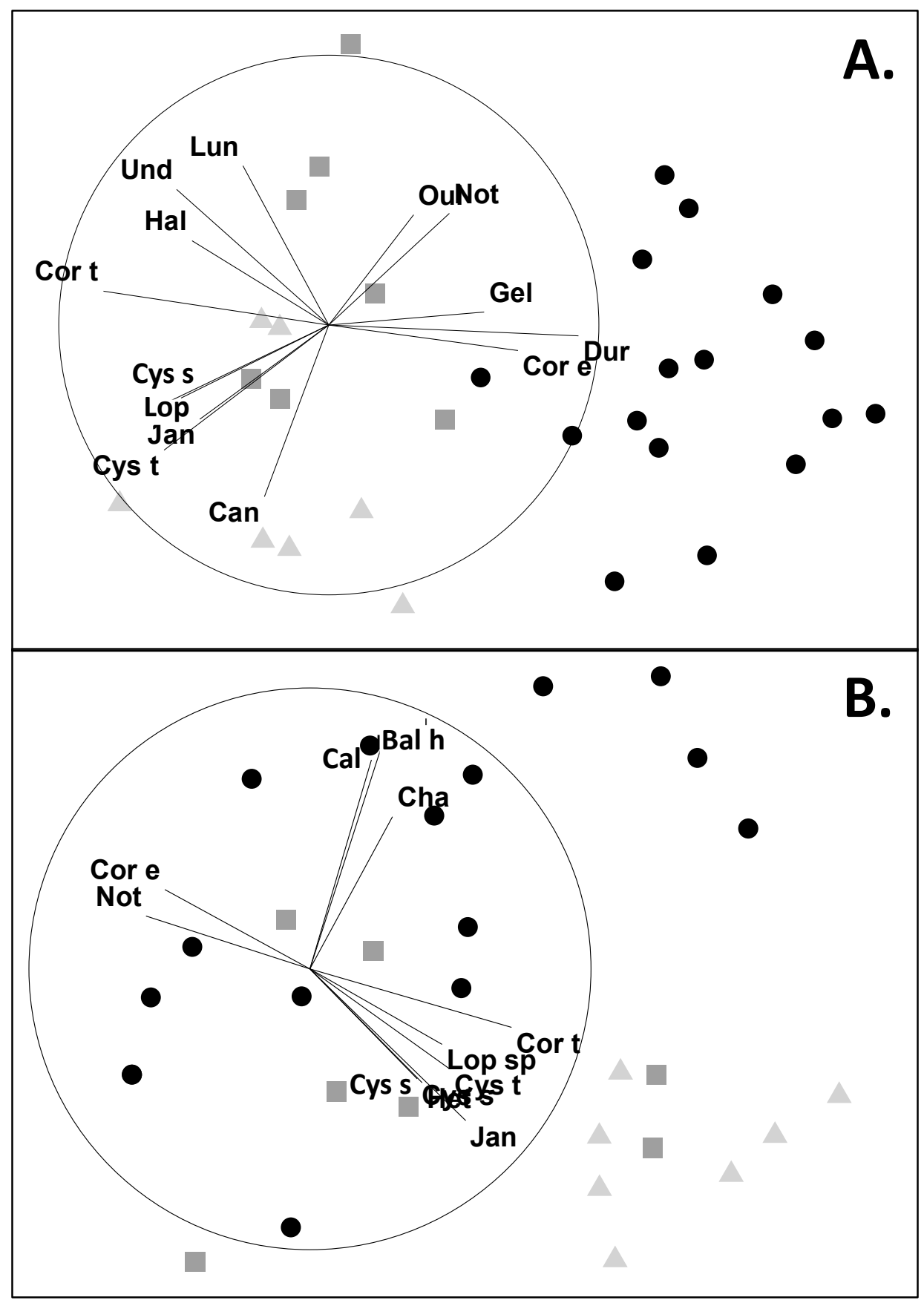

Figure 2. MDS of abundance data (A) and attachment links (B) showing relative similarity between plots dominated by Durvillaea spp. ( $n=16$, black circles), Undaria pinnatifida ( $n=7$, dark grey squares) or Cystophora spp. ( $n=7$, Light grey triangle) in September 2018 (all 30 plots were Durvillaea spp. habitats in 2012). Plot A stress $=0.16$ and plot B stress $=0.19$. Data were analysed with the Bray Curtis dissimilarity index. Vector overlays represent $50 \%$ of the total community variation. See online supplement 1 for species abbreviation list. 

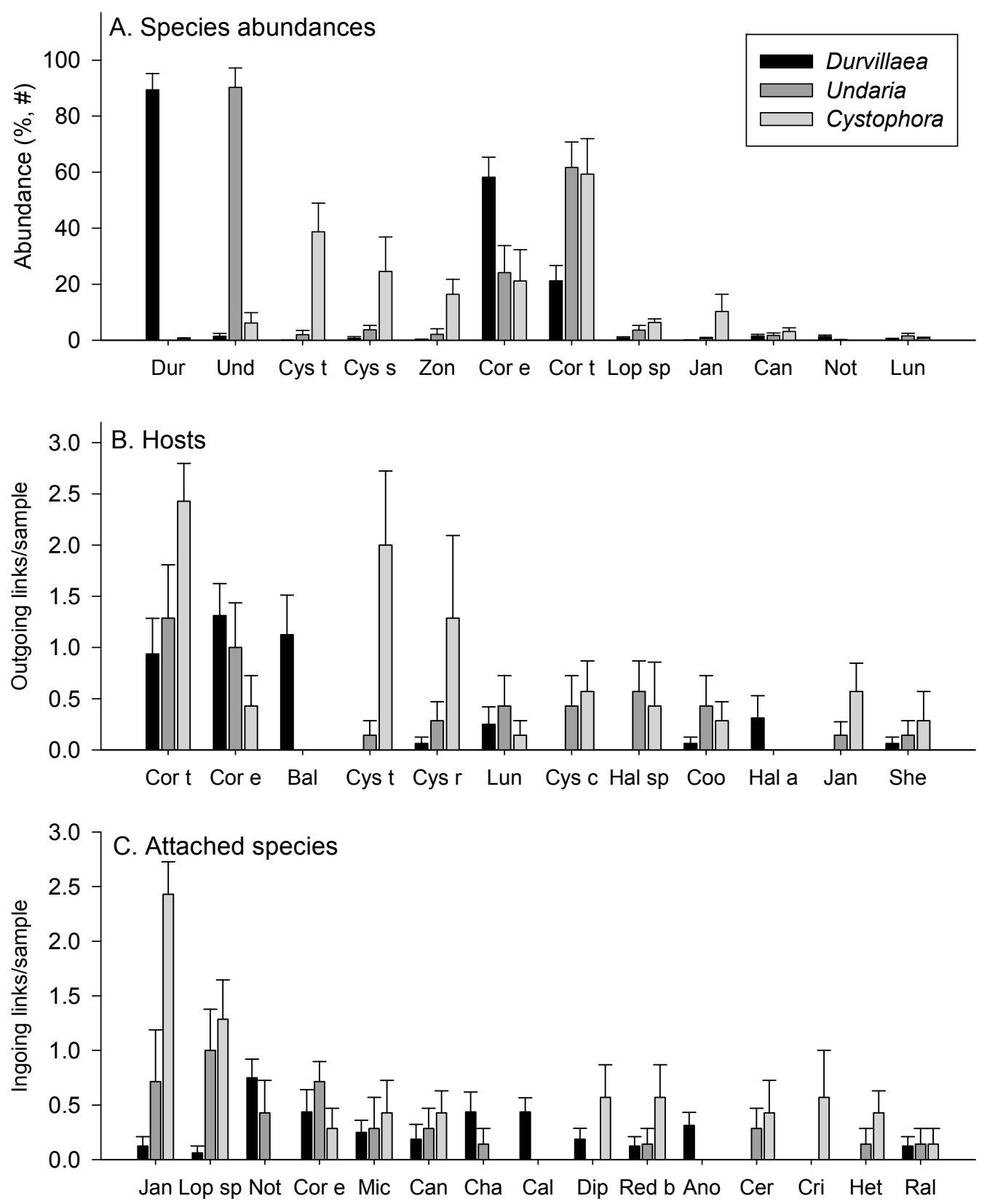

Figure 3. Mean (+SE) abundance (A), outgoing links (hosts) (B) and incoming links (attached species) (C) in plots dominated by Durvillaea spp. $(n=16)$, Undaria pinnatifida $(n=7)$ or Cystophora spp. $(n=7)$ in September 2018 (all 30 plots were Durvillaea spp. forests in 2012). Abundance data are shown for taxa contributing $90 \%$ of the similarity within each of the habitat types (similarity was calculated from standardised species-sample matrix, see method section). Abundances represent mean percent cover for sessile species and mean densities per plot for mobile species (Can, Not, Lun). B and C are shown for taxa with more than 3 links across the 3 habitat types. See online supplement 1 for species abbreviation list.

Finally, there appeared to be a separation in the total network between habitats dominated by Durvillaea spp. (Figure 4A) and Cystophora spp. (Figure 4B). For example, Durvillaea spp. was absent from 'its own network', which instead was dominated by a few central nodes around B. hirsuta and encrusting corallines (Figure 4A). By comparison, the total $U$. pinnatifida network was more variable and encapsulated many of the species and their interactions that were encountered in both the Durvillaea spp. and Cystophora spp. networks (Figure 4C). Finally, the entire 'landscape' network that encompassed all 
the three habitat types (Figure 4D) highlighted in a single graph (a) the central nodes around B. hirsuta, coralline turf and encrusting corallines, (b) the absence of Durvillaea spp. from attachment interactions, and (c) the many links to mobile species that included snails, limpets, and chitons.

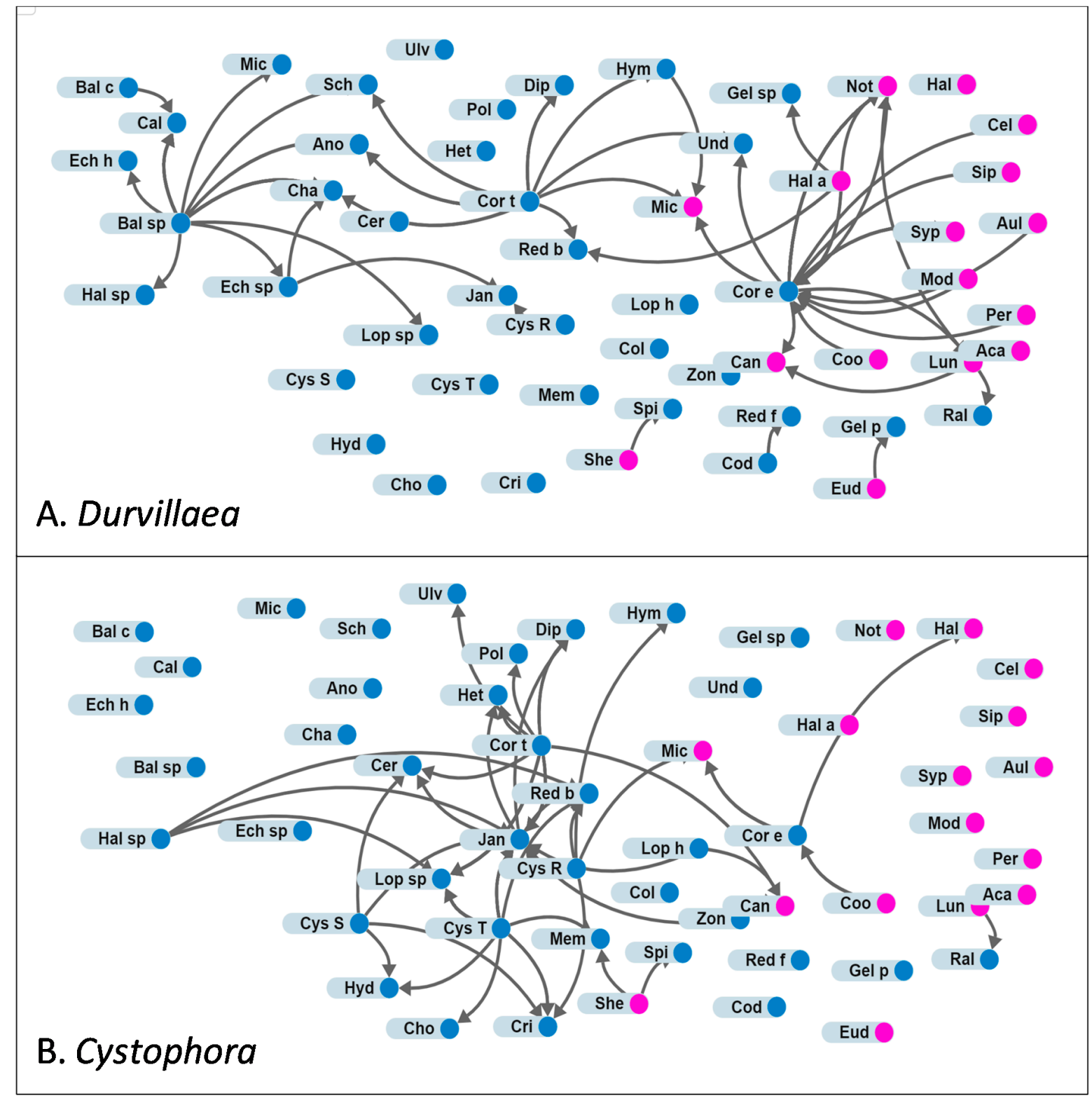

Figure 4. Cont. 


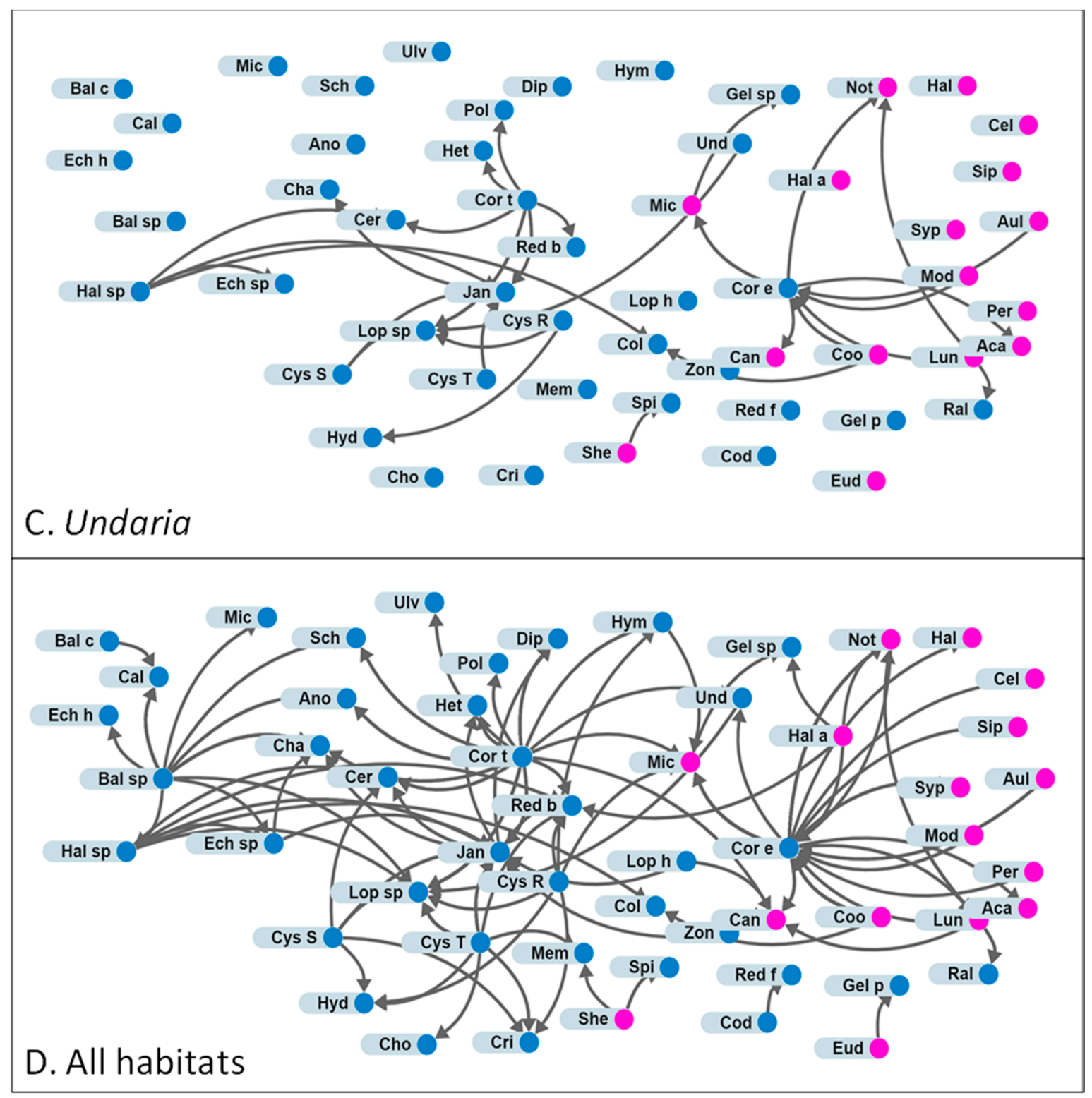

Figure 4. Networks showing interactions between hosts (with outgoing arrows/links) and attached species (with incoming arrows/links) in plots dominated by Durvillaea spp. (A. $n=16)$, Cystophora spp. (B. $n=7)$, Undaria pinnatifida (C. $n=7$ ) and across all three habitats (D. $n=30$ ) in September 2018 (all 30 plots were Durvillaea spp. forests in 2012). Blue $=$ sessile species, Pink $=$ mobile species.

\section{Discussion}

\subsection{Introduction}

Foundation species are often identified from species-abundance data and per capita effects derived from experimental manipulations $[2,12,92,93]$. Here, we used classical abundance data to show that the southern bull kelps are 'primary' foundation species, because these abundant and large species had strong control over community structure [52,70,75,76,81]. Indeed, when southern bull kelps were physically removed over six years, or recently lost following a marine heatwave, communities changed dramatically resulting in replacement by other large canopy-forming macroalgae (alternative foundation species) with different associated epiphytes (secondary foundation species) and understory species, as has been shown in other experiments [70,79]. Furthermore, supplementary analyses of attachment interaction networks between primary and alternative foundation species highlighted different 
relationships among plots dominated by Durvillaea spp., Cystophora spp. and U. pinnatifida [14,46]. For example, the overlooked, apparently obligate, southern bull kelp-associated alga B. hirsuta, was a host for a range of epiphytes and thereby magnified local biodiversity, only to be lost along with the canopy of Durvillaea. This attachment network analysis showed similarities to terrestrial networks on pollinator visitations ( $\cong$ attachment) and seed dispersers in mutualistic networks [21,94-96], or epiphytes on trees in commensal networks [26,28,31,32,34]. However, in contrast to these bipartite networks, where organisms A and B attach to organisms C or D (but not vice versa), our attachment network is bidirectional, allowing for reciprocal attachments between many species, highlighting low host-specificity of marine organisms [14,46,97-99].

\subsection{Comparing Habitats Dominated by Durvillaea spp., Undaria pinnatifida or Cystophora spp.}

The loss of Durvillaea spp. resulted in large changes in abundances of many other taxa, highlighting that southern bull kelps are the primary foundation species that control sub-canopy biodiversity, as previously shown for this region [79]. Following their loss, Durvillaea spp. were replaced by other canopy-forming macroalgae that could also be considered (alternative) foundation species. However, the alternative foundation species did not entirely replace the ecological function of Durvillaea spp. because encrusting coralline algae, low-lying foliose taxa and small grazers were almost absent in the new habitats [93]. Instead, different assemblages developed with high cover of coralline turf and a suite of epiphytic algae that were either rare or absent in Durvillaea spp. dominated plots. These differences in assemblages are likely due to differences in morphology, sizes and growth rates between primary and alternative foundation species. For example, Durvillaea spp. are much larger, heavier and therefore have stronger whiplash and shading effects compared to Cystophora spp. and U. pinnatifida [70,100,101]. Interestingly, Durvillaea spp. was not a host for epiphytes, probably because its smooth heavy blade and continued wave action result in strong whiplash effects $[64,70,79,102,103]$. It is also possible that Durvillaea spp. have chemical defences against epiphytes [104]. However, the Cystophora spp. that replaced Durvillaea spp. can also control patterns of diversity [61,93]. Our results show that Cystophora spp. were alternative foundation species, because they modified the abundances of other species and played a central role in attachment networks. In other words, Cystophora spp. both modify and create habitat. The many plants and animals found attached to Cystophora spp. may be related to their complex perennial morphology with many short branchlets and distinct retroflexed main axes and stipes $[105,106]$ that provide attachment points and favourable microclimates [100]. By comparison, $U$. pinnatifida appears to be an alternative foundation species only in terms of its own high abundance [84]. Perhaps this large kelp should not be considered a foundation species at all, because $U$. pinnatifida has a relatively low impact on community structure, mainly reducing the abundance of small ephemeral or seasonal algae $[84,101,107,108]$. Furthermore, U. pinnatifida was host to only a few attached species (Figure 3A), likely because of its short-lived macroscopic frond (4-7 months), rapid growth, simple blade morphology and slippery texture that can prevent attachment. Note, however, that taxa concealed within the holdfasts were not enumerated here. Biodiversity associated with the large and complex holdfast structures of Durvillaea spp. and $U$. pinnatifida could increase the importance of these two species as primary and alternative foundation species, compared to Cystophora spp. that only have small and structurally simple holdfasts [109-112].

In this study, coralline algae were abundant primary (host) and secondary (epiphyte) species. Coralline algae are common in marine systems and can be hosts to many invertebrate and algal species [113-117]. Encrusting coralline algae were likely indirectly facilitated by Durvillaea spp., as larger and stronger macroalgal competitors are often excluded by canopy-forming kelps through shading and whiplash effects $[53,69,70,102,118-120]$. These encrusting algae were important hosts for mobile invertebrates such as the diminutive limpets Notoacmea spp., and the abalone, Haliotis australis, but became less common when Durvillaea spp. (and associated encrusting corallines) were replaced by Cystophora spp. and U. pinnatifida and their understories of turfs. Limpets can increase 
their movements to avoid such complex substrates [121,122] and may also have experienced increased predation by fish and crustaceans in the absence of the Durvillaea spp. canopy [123]. Alternatively, the encrusting coralline algae (or biofilms thereon) could have been primary food resource for the limpets with their abundance declining in relation to their food source [124].

The subsequent increase of coralline turfs following the loss of Durvillaea spp. facilitated several algal taxa that recruited and attached to its fronds [114,115]. As such, coralline algae turfs could perhaps also be considered alternative foundation species, especially because they can also inhibit recruitment of larger canopy-forming algae [53,71,125-128] including Durvillaea spp. Furthermore, coralline turfs can colonise space soon after disturbances [70,79]. It is possible that the expansion of turfs in repeated removal plots prevented recovery of southern bull kelps. It was therefore surprising that Cystophora spp., with similar reproductive strategies to southern bull kelp [67], became dominant in several plots with high turf cover. The mechanisms underpinning the successful colonization of Cystophora spp. in this turf habitat require further scrutiny.

In addition to coralline algae that were abundant and common central host species across plots, there were several unexpected central host species whose abundances and interactions varied among the three types of habitat. In the Durvillaea spp. habitat, the small, red alga B. hirsuta was an important host for small algae such as the red blade $C$. calibletharoides and the tubular green alga C. colliformis, despite its low abundance ( $<1 \%$ cover). Furthermore, B. hirsuta and its epiphyte C. calibletharoides, appear to be obligate understory species that were not detected outside of the Durvillaea spp. habitat, highlighting how different types of foundation species interact to maintain biodiversity [12]. This demonstrates that species we know little about (e.g., B. hirsuta, A. crinitum, C. coliformis) can provide functions that are overlooked in abundance surveys. Finally, several shell-forming snails, including L. smaragda and Notoacmea spp, were found to be mobile primary (hosts) and secondary (attached) foundation species that were embedded within the larger macroalgal habitats. This result supports the findings of other studies that suggest that snails can be mobile foundation species that control small-scale patterns of biodiversity [41,129-132]. In our study, the relative importance of shell-formers varied among habitats. For example, shells were more important as hosts for encrusting coralline algae, Ralfsia sp. and Notoacmea spp. in plots dominated by U. pinnatifida or Cystophora spp.

Two of the most important epiphytes were the articulated coralline alga J. sphaeroramosa and the bushy red alga L. hirtum. The success of J. sphaeroramosa and L. hirtum in plots dominated by U. pinnatifida and Cystophora spp. are likely due to their low substrate affinities allowing them to recruit to a wide range of host species including the long-lived and abundant Cystophora spp. [100,133]. However, J. sphaeroramosa and L. hirtum are likely limited by shading and whiplash in the Durvillaea spp. habitat [70]. Finally, some species, like J. sphaeroramosa and L. hirtum, had dual roles as hosts and attached species. These dual roles suggest that even species that are often considered subordinate, such as L. hirtum [107], can be central links in habitat cascades and play an important role in biodiversity networks $[13,14,46,134]$.

Our experiment had a few limitations. First, we did not control the abundance of Cystophora spp. or U. pinnatifida (and other possible co-varying factors) that potentially could explain their effects. For example, Cystophora spp. and U. pinnatifida plots where also characterised by different periods of time since Durvillaea spp. was lost, and effects may therefore represent successional sequences. Second, we did not control the heatwave, and our study, like most heatwave studies $[53,135,136]$ is a natural experiment [137]. Although other factors could have contributed to the recent loss of Durvillaea spp., we argue that high temperature was the most important stress factor [see 52 for details]. Finally, we did not control which species of Durvillaea survived and which died following the heatwave. All plots had similar elevation but other factors, like micro-topography of the substrate or Durvillaea spp. patch sizes may have co-varied with heat-stress effects. Nevertheless, irrespective of any co-variation, our experiment unequivocally demonstrated that plots dominated by Durvillaea spp. in 2012 can transform into habitats dominated by either Cystophora spp. or U. pinnatifida. 


\subsection{The Future of Durvillaea Beds in New Zealand}

The future of some New Zealand Durvillaea spp. populations is presently in doubt due to heatwave-induced die-backs and dramatic changes in shore height following seismic uplift in central New Zealand $[52,80]$. Durvillaea spp. are cold-water macroalgae with a circumpolar distribution that could be restricted in a warmer ocean $[138,139]$. Our results suggest that future losses of Durvillaea spp. may result in increased cover of alternative foundation species that are presently uncommon beneath full Durvillaea spp. canopies [79]. These alternative foundation species include the perennial canopy-forming species such as Cystophora spp. or weedy species such as U. pinnatifida. However, it is also possible that Durvillaea spp. will be replaced by much smaller ephemeral or foliose turf-forming species as warmer waters promote ephemeral, weedy algae [140]. There is increasing concern worldwide that canopy-forming macroalgae are becoming less resilient to physical disturbances and physiological stress and are being replaced by small and weedy turfing species [71]. In our study, the original habitat, dominated by Durvillaea spp., encrusting coralline understory and small invertebrates, was replaced by other canopy-forming macroalgae, an understory of coralline turf, and many more epiphytes. This expansion of turf will likely compound the effects of canopy loss by creating an unfavourable habitat for Durvillaea spp. to recolonise, despite nearby reproductive populations in the intact Durvillaea spp. habitat $[71,141]$. Furthermore, colonizing Durvillaea recruits can experience intense herbivory from the butterfish, Odax pullus that typically grazes outside of dense stands of Durvillaea spp. [123].

\subsection{Research Gaps and Conclusions}

We documented changes to different types of foundation species based on two types of supplementary data that are relatively simple to collect in the field. However, to better understand the functioning of foundation species in marine benthic systems, future studies should also examine how and why secondary foundation species are attached to and affect their primary foundation species hosts. A further important line of research should asses how specific linkages between hosts and attached species modify ecosystem stability and resilience. For example, documenting whether secondary foundation species select primary foundation species because of facilitative properties (e.g., habitat modification) or to avoid enemies or stress, will provide insight into underpinning mechanisms that control attachment networks and facilitation and habitat cascades [14,46,97-99,142,143]. In addition, incorporating impacts of modified drag, shading, nutrient levels or hydrodynamic regimes from secondary foundation species [144] would enhance our understanding of ecosystem functioning, resilience and stability [145]. Finally, new insight into how foundation species affect biodiversity could arise by combining attachment networks with traditional trophic and competition networks, and by studying their relative importance along environmental stress gradients (e.g., desiccation and temperature stress along elevation and latitudinal gradients).

We found that Durvillaea spp., Cystophora spp. and $U$. pinnatifida can be co-occurring foundation species on wave-exposed intertidal rocky shores in New Zealand. In addition, Cystophora spp. and $U$. pinnatifida can benefit from stressors and disturbance that reduce the cover of Durvillaea spp. However, Durvillaea spp., Cystophora spp. and $U$. pinnatifida can be considered foundation species for different reasons. Durvillaea spp. controlled the abundances of other species and local biodiversity networks whereas Cystophora spp. became abundant in the absence of Durvillaea spp. but played a central role as a host to many epiphytes. By contrast, U. pinnatifida was mainly important due to its high abundance, with less effect on attachment networks, suggesting that it is less important in controlling biodiversity. Finally, we recommend that future studies should combine supplementary sampling and analytical methods to identify different types of foundation species, such as the abundance and network analyses used in this study, to better understand processes that control biodiversity and ecosystem functions. 
Supplementary Materials: The following are available online at http:/ /www.mdpi.com/1424-2818/11/4/56/ s1, Table S1: List of taxa found in abundance and attachment surveys, Table S2: Network terminology and measured metrics.

Author Contributions: Formal analysis, M.S.T.; Investigation, M.S.T. and P.M.S.; Methodology, M.S.T. and P.M.S.; Writing—original draft, M.S.T.; Writing—review \& editing, M.S.T. and P.M.S.

Funding: This study was funded by the Marsden Fund of The Royal Society of New Zealand (13-UOC-106) and the Brian Mason Trust (Impacts of an unprecedented marine heatwave on bull kelp forests and implications for conservation and restoration) to MST. PMS is funded by Cawthron Institute.

Conflicts of Interest: The authors declare no conflict of interest.

\section{References}

1. Dayton, P.K. Towards an understanding of community resilience and the potential effects of enrichment to the benthos of McMurdo Sound, Antarctica. In Proceedings of the Colloquium on Conservation Problems in Antartica; Parker, B.C., Ed.; Allen Press: Lawrence, KS, USA, 1972; pp. 81-96.

2. Jones, C.G.; Lawton, J.H.; Shachak, M. Organisms as ecosystem engineers. Oikos 1994, 69, 373-386. [CrossRef]

3. Power, M.E.; Tilman, D.; Estes, J.A.; Menge, B.A.; Bond, W.J.; Mills, L.S.; Daily, G.; Castilla, J.C.; Lubchenco, J.; Paine, R.T. Challenges for the quest for keystones. BioScience 1996, 46, 609-620. [CrossRef]

4. Hanski, I. Dynamics of regional distribution: The core and satellite species hypothesis. Oikos 1982, 38, 210-221. [CrossRef]

5. Huston, M.A. Biological Diversity: The Coexistence of Species on Changing Landscapes; Cambridge University Press: Cambridge, UK, 1994; p. 681.

6. Darwin, C. The Origin of Species; The Modern Library: New York, NY, USA, 1859; p. 686.

7. Möbius, K. Die Auster und die Austernwirtschaft; Wiegundt, Hempel and Parey: Berlin, Germany, $1877 ;$ p. 126.

8. Ellison, A.M.; Bank, M.S.; Clinton, B.D.; Colburn, E.A.; Elliott, K.; Ford, C.R.; Foster, D.R.; Kloeppel, B.D.; Knoepp, J.D.; Lovett, G.M. Loss of foundation species: Consequences for the structure and dynamics of forested ecosystems. Front. Ecol. Environ. 2005, 3, 479-486. [CrossRef]

9. Yakovis, E.L.; Artemieva, A.V.; Shunatova, N.N.; Varfolomeeva, M.A. Multiple foundation species shape benthic habitat islands. Oecologia 2008, 155, 785-795. [CrossRef] [PubMed]

10. Wootton, J.T. Estimates and tests of per capita interaction strength: Diet, abundance, and impact of intertidally foraging birds. Ecol. Monogr. 1997, 67, 45-64. [CrossRef]

11. Paine, R.T. Food-web analysis through field measurement of per capita interaction strength. Nature 1992, 355, 73. [CrossRef]

12. Dayton, P.K. Experimental Evaluation of Ecological Dominance in a Rocky Intertidal Algal Community. Ecol. Monogr. 1975, 45, 137-159. [CrossRef]

13. Thomsen, M.S.; Altieri, A.H.; Angelini, C.; Bishop, M.J.; Gribben, P.E.; Lear, G.; He, Q.; Schiel, D.R.; Silliman, B.R.; South, P.M. Secondary foundation species enhance biodiversity. Nat. Ecol. Evol. 2018, 2, 634. [CrossRef]

14. Yakovis, E.; Artemieva, A. Cockles, barnacles and ascidians compose a subtidal facilitation cascade with multiple hierarchical levels of foundation species. Sci. Rep. 2017, 7, 237. [CrossRef]

15. Angelini, C.; Altieri, A.H.; Silliman, B.R.; Bertness, M.D. Interactions among foundation species and their consequences for community organization, biodiversity, and conservation. BioScience 2011, 61, 782-789. [CrossRef]

16. Dijkstra, J.A.; Boudreau, J.; Dionne, M. Species-specific mediation of temperature and community interactions by multiple foundation species. Oikos 2012, 121, 646-654. [CrossRef]

17. Ellison, A.M.; Barker-Plotkin, A.A.; Foster, D.R.; Orwig, D.A. Experimentally testing the role of foundation species in forests The Harvard Forest Hemlock Removal Experiment. Methods Ecol. Evol. 2010, 1, 168-179. [CrossRef]

18. Tylianakis, J.M.; Morris, R.J. Ecological networks across environmental gradients. Annu. Rev. Ecol. Evol. Syst. 2017, 48. [CrossRef]

19. Blüthgen, N. Why network analysis is often disconnected from community ecology: A critique and an ecologist's guide. Basic Appl. Ecol. 2010, 11, 185-195. [CrossRef] 
20. Dunne, J.A.; Williams, R.J.; Martinez, N.D. Food-web structure and network theory: The role of connectance and size. Proc. Natl. Acad. Sci. USA 2002, 99, 12917-12922. [CrossRef]

21. Bascompte, J.; Jordano, P. Mutualistic Networks; Princeton University Press: Princeton, NJ, USA, 2013.

22. Ollerton, J.; McCollin, D.; Fautin, D.G.; Allen, G.R. Finding NEMO: Nestedness engendered by mutualistic organization in anemonefish and their hosts. Proc. R. Soc. B Biol. Sci. 2006, 274, 591-598. [CrossRef] [PubMed]

23. Floeter, S.R.; Vázquez, D.P.; Grutter, A.S. The macroecology of marine cleaning mutualisms. J. Anim. Ecol. 2007, 76, 105-111. [CrossRef] [PubMed]

24. Ricciardi, F.; Boyer, M.; Ollerton, J. Assemblage and interaction structure of the anemonefish-anemone mutualism across the Manado region of Sulawesi, Indonesia. Environ. Biol. Fishes 2010, 87, 333-347. [CrossRef]

25. Quimbayo, J.P.; Cantor, M.; Dias, M.S.; Grutter, A.S.; Gingins, S.; Becker, J.H.; Floeter, S.R. The global structure of marine cleaning mutualistic networks. Glob. Ecol. Biogeogr. 2018, 27, 1238-1250. [CrossRef]

26. Burns, K. Network properties of an epiphyte metacommunity. J. Ecol. 2007, 95, 1142-1151. [CrossRef]

27. Burns, K.; Zotz, G. A hierarchical framework for investigating epiphyte assemblages: Networks, meta-communities, and scale. Ecology 2010, 91, 377-385. [CrossRef] [PubMed]

28. Blick, R.; Burns, K.; Moles, A. Predicting network topology of mistletoe-host interactions: Do mistletoes really mimic their hosts? Oikos 2012, 121, 761-771. [CrossRef]

29. Blick, R.; Burns, K.; Moles, A. Dominant network interactions are not correlated with resource availability: A case study using mistletoe host interactions. Oikos 2013, 122, 889-895. [CrossRef]

30. Sáyago, R.; Lopezaraiza-Mikel, M.; Quesada, M.; Álvarez-Añorve, M.Y.; Cascante-Marín, A.; Bastida, J.M. Evaluating factors that predict the structure of a commensalistic epiphyte-phorophyte network. Proc. R. Soc. B Biol. Sci. 2013, 280, 20122821. [CrossRef] [PubMed]

31. Zhao, M.; Geekiyanage, N.; Xu, J.; Khin, M.M.; Nurdiana, D.R.; Paudel, E.; Harrison, R.D. Structure of the epiphyte community in a tropical montane forest in SW China. PloS ONE 2015, 10, e0122210. [CrossRef]

32. Taylor, A.; Saldaña, A.; Zotz, G.; Kirby, C.; Díaz, I.; Burns, K. Composition patterns and network structure of epiphyte-host interactions in Chilean and New Zealand temperate forests. N. Z. J. Bot. 2016, 54, $204-222$. [CrossRef]

33. Francisco, T.M.; Couto, D.R.; Evans, D.M.; Garbin, M.L.; Ruiz-Miranda, C.R. Structure and robustness of an epiphyte-phorophyte commensalistic network in a neotropical inselberg. Austral Ecol. 2018, 43, 903-914. [CrossRef]

34. Zotarelli, H.G.; Molina, J.M.; Ribeiro, J.E.; Sofia, S.H. A commensal network of epiphytic orchids and host trees in an Atlantic Forest remnant: A case study revealing the important role of large trees in the network structure. Austral Ecol. 2019, 44, 114-125. [CrossRef]

35. Wahl, M. Marine epibiosis. I. Fouling and antifouling: Some basic aspects. Mar. Ecol. Prog. Ser. 1989, 58, 175-189. [CrossRef]

36. Buza-Jacobucci, G.; Pereira-Leite, F.P. The role of epiphytic algae and different species of Sargassum in the distribution and feeding of herbivorous amphipods. Lat. Am. J. Aquat. Res. 2014, 42, 353-363. [CrossRef]

37. Cruz-Angon, A.; Baena, M.L.; Greenberg, R. The contribution of epiphytes to the abundance and species richness of canopy insects in a Mexican coffee plantation. J. Trop. Ecol. 2009, 45, 453-463. [CrossRef]

38. Edgar, G.J.; Robertson, A.I. The influence of seagrass structure on the distribution and abundance of mobile epifauna: Pattern and processes in a Western Australian Amphibolis bed. J. Exp. Mar. Biol. Ecol. 1992, 160, 13-31. [CrossRef]

39. Pettersson, R.B.; Ball, J.P.; Renhorn, K.-E.; Esseen, P.-A.; Sjöberg, K. Invertebrate communities in boreal forest canopies as influenced by forestry and lichens with implications for passerine birds. Biol. Conserv. 1995, 74, 57-63. [CrossRef]

40. Viejo, R.M.; Åberg, P. Temporal and spatial variation in the density of mobile epifauna and grazing damage on the seaweed Ascophyllum nodosum. Mar. Biol. 2003, 142, 1229-1241. [CrossRef]

41. Thomsen, M.S.; Wernberg, T.; Altieri, A.; Tuya, F.; Gulbransen, D.; McGlathery, K.J.; Holmer, M.; Silliman, B.R. Habitat cascades: The conceptual context and global relevance of facilitation cascades via habitat formation and modification. Integr. Comp. Biol. 2010, 50, 158-175. [CrossRef] [PubMed]

42. Angelini, C.; Silliman, B.R. Secondary foundation species as drivers of trophic and functional diversity: Evidence from a tree-epiphyte system. Ecology 2014, 95, 185-196. [CrossRef] 
43. Angelini, C.; Briggs, K.L. Spillover of secondary foundation species transforms community structure and accelerates decomposition in oak savannas. Ecosystems 2015, 18, 780-791. [CrossRef]

44. Altieri, A.H.; Silliman, B.R.; Bertness, M.D. Hierarchical organization via a facilitation cascade in intertidal cordgrass bed communities. Am. Nat. 2007, 169, 195-206. [CrossRef]

45. Bittick, S.J.; Clausing, R.J.; Fong, C.R.; Fong, P. Bolstered physical defences under nutrient-enriched conditions may facilitate a secondary foundational algal species in the South Pacific. J. Ecol. 2016, 104, 646-653. [CrossRef]

46. Thomsen, M.S.; Hildebrand, T.; South, P.M.; Foster, T.; Siciliano, A.; Oldach, E.; Schiel, D.R. A sixth-level habitat cascade increases biodiversity in an intertidal estuary. Ecol. Evol. 2016, 6, 8291-8303. [CrossRef] [PubMed]

47. Halpern, B.S.; Silliman, B.R.; Olden, J.D.; Bruno, J.P.; Bertness, M.D. Incorporating positive interactions in aquatic restoration and conservation. Front. Ecol. Environ. 2007, 5, 153-160. [CrossRef]

48. Crain, C.M.; Bertness, M.D. Ecosystem engineering across environmental gradients: Implications for conservation and management. Bioscience 2006, 56, 211-218. [CrossRef]

49. Posada, J.M.; Aide, T.M.; Cavelier, J. Cattle and weedy shrubs as restoration tools of tropical montane rainforest. Restor. Ecol. 2000, 8, 370-379. [CrossRef]

50. Gratton, C.; Denno, R.F. Restoration of arthropod assemblages in a Spartina salt marsh following removal of the invasive plant Phragmites australis. Restor. Ecol. 2005, 13, 358-372. [CrossRef]

51. Rickey, M.A.; Anderson, R.C. Effects of nitrogen addition on the invasive grass Phragmites australis and a native competitor Spartina pectinata. J. Appl. Ecol. 2004, 41, 888-896. [CrossRef]

52. Thomsen, M.S.; Mondardini, L.; Alestra, A.; Gerrity, S.; Tait, L.; South, P.M.; Lilley, S.A.; Schiel, D.R. Local extinction of bull kelp (Durvillaea spp.) due to a marine heatwave. Front. Mar. Sci. 2019, 6, 84-92. [CrossRef]

53. Wernberg, T.; Bennett, S.; Babcock, R.C.; de Bettignies, T.; Cure, K.; Depczynski, M.; Dufois, F.; Fromont, J.; Fulton, C.J.; Hovey, R.K. Climate-driven regime shift of a temperate marine ecosystem. Science 2016, 353, 169-172. [CrossRef]

54. McCook, L.; Jompa, J.; Diaz-Pulido, G. Competition between corals and algae on coral reefs: A review of evidence and mechanisms. Coral reefs 2001, 19, 400-417. [CrossRef]

55. Rykiel, J.R.; Edward, J. Towards a definition of ecological disturbance. Aust. J. Ecol. 1985, 10, 361-365. [CrossRef]

56. Borics, G.; Várbíró, G.; Padisák, J. Disturbance and stress: Different meanings in ecological dynamics? Hydrobiologia 2013, 711, 1-7. [CrossRef]

57. Grime, J.P. Plant strategies and vegetation processes. In Plant Strategies and Vegetation Processes; Springer: Berlin/Heidelberg, Germany, 1979.

58. Beisner, B.E.; Haydon, D.T.; Cuddington, K. Alternative stable states in ecology. Front. Ecol. Environ. 2003, 1, 376-382. [CrossRef]

59. Suding, K.N.; Gross, K.L.; Houseman, G.R. Alternative states and positive feedbacks in restoration ecology. Trends Ecol. Evol. 2004, 19, 46-53. [CrossRef] [PubMed]

60. Didham, R.K.; Tylianakis, J.M.; Hutchison, M.A.; Ewers, R.M.; Gemmell, N.J. Are invasive species the drivers of ecological change? Trends Ecol. Evol. 2005, 20, 470-474. [CrossRef] [PubMed]

61. South, P.M.; Thomsen, M.S. The ecological role of invading Undaria pinnatifida: An experimental test of the driver-passenger models. Mar. Biol. 2016, 163, 175. [CrossRef]

62. Bauer, J.T. Invasive species:“back-seat drivers” of ecosystem change? Biol. Invasions 2012, 14, 1295-1304. [CrossRef]

63. Bulleri, F.; Balata, D.; Bertocci, I.; Tamburello, L.; Benedetti-Cecchi, L. The seaweed Caulerpa racemosa on Mediterranean rocky reefs: From passenger to driver of ecological change. Ecology 2010, 91, 2205-2212. [CrossRef]

64. Dayton, P.K. Ecology of kelp communities. Annu. Rev. Ecol. Syst. 1985, 16, 215-245. [CrossRef]

65. Coleman, M.A.; Wernberg, T. Forgotten underwater forests: The key role of fucoids on Australian temperate reefs. Ecol. Evol. 2017, 7, 8406-8418. [CrossRef]

66. Teagle, H.; Hawkins, S.J.; Moore, P.J.; Smale, D.A. The role of kelp species as biogenic habitat formers in coastal marine ecosystems. J. Exp. Mar. Biol. Ecol. 2017, 492, 81-98. [CrossRef] 
67. Schiel, D.R.; Foster, M.S. The population biology of large brown seaweeds: Ecological consequences of multiphase life histories in dynamic coastal environments. Annu. Rev. Ecol. Evol. Syst. 2006, 37, 343-372. [CrossRef]

68. Steneck, R.S.; Graham, M.H.; Bourque, B.J.; Corbett, D.; Erlandson, J.M.; Estes, J.A.; Tegner, M.J. Kelp forest ecosystems: Biodiversity, stability, resilience and future. Environ. Conserv. 2002, 29, 436-459. [CrossRef]

69. Toohey, B.; Kendrick, G.A.; Wernberg, T.; Phillips, J.C.; Malkin, S.; Prince, J. The effects of light and thallus scour from Ecklonia radiata canopy on an associated foliose algal assemblage: The importance of photoacclimation. Mar. Biol. 2004, 144, 1019-1027. [CrossRef]

70. Taylor, D.I.; Schiel, D.R. Self-replacement and community modification by the southern bull kelp Durvillaea antarctica. Mar. Ecol. Prog. Ser. 2005, 288, 87-102. [CrossRef]

71. Filbee-Dexter, K.; Wernberg, T. Rise of turfs: A new battlefront for globally declining kelp forests. BioScience 2018, 68, 64-76. [CrossRef]

72. Airoldi, L. The effects of sedimentation on rocky coast assemblages. Oceanogr. Mar. Biol. 2003, 41, 169-171.

73. Connell, S.D.; Russell, B.D. The direct effects of increasing $\mathrm{CO}_{2}$ and temperature on non-calcifying organisms: Increasing the potential for phase shifts in kelp forests. Proc. R. Soc. B Biol. Sci. 2010, 277, 1409-1415. [CrossRef] [PubMed]

74. Thomsen, M.S.; Wernberg, T.; South, P.M.; Schiel, D.R. Non-native seaweeds drive changes in marine coastal communities around the world. In Seaweed phylogeography; Springer: Berlin/Heidelberg, Germany, 2016; pp. 147-185.

75. Hay, C.H. Some factors affecting the upper limit of the southern bull kelp Durvillaea antarctica (Chamisso) Hariot on two New Zealand shores. J. R. Soc. N. Z. 1979, 9, 279-287. [CrossRef]

76. Hurd, C. Bull kelp. In The Living Reef-The Ecology of New Zealand's Rocky Reefs; Andrew, N., Francis, M., Eds.; Craig Potton Publishing: Nelson, New Zealand, 2003; pp. 56-63.

77. Hay, C.H. Biological study of Durvillaea antarctica (Chamisso) Hariot and D. Willana Lindauer in New Zealand. Ph.D. Thesis, University of Canterbury, Canterbury, New Zealand, 1977; p. 332.

78. Smith, S.; Simpson, R. Effects of the 'Nella Dan'oil spill on the fauna of Durvillaea antarctica holdfasts. Mar. Ecol. Prog. Ser. 1995, 121, 73-89. [CrossRef]

79. Schiel, D.R.; Lilley, S.A.; South, P.M. Ecological tipping points for an invasive kelp in rocky reef algal communities. Mar. Ecol. Prog. Ser. 2018, 587, 93-104. [CrossRef]

80. Schiel, D.R.; Alestra, T.; Gerrity, S.; Orchard, S.; Dunmore, R.A.; Pirker, J.; Lilley, S.A.; Tait, L.; Thomsen, M.S. The Kaikōura earthquake in southern New Zealand: Loss of connectivity of marine communities and the necessity of a cross-ecosystems perspective. Aquat. Conserv. Mar. Freshw. Ecosyst 2019, in press.

81. Westermeier, R.; Müller, D.G.; Gómez, I.; Rivera, P.; Wenzel, H. Population biology of Durvillaea antarctica and Lessonia nigrescens (Phaeophyta) on the rocky shores of southern Chile. Mar. Ecol. Prog. Ser. 1994, 110, 187-194. [CrossRef]

82. Castilla, J.C. Earthquake-caused coastal uplift and its effects on rocky intertidal kelp communities. Science 1988, 242, 440-443. [CrossRef] [PubMed]

83. Barner, A.K.; Hacker, S.D.; Menge, B.A.; Nielsen, K.J. The complex net effect of reciprocal interactions and recruitment facilitation maintains an intertidal kelp community. J. Ecol. 2016, 104, 33-43. [CrossRef]

84. Thomsen, M.S.; Wernberg, T.; South, P.M.; Schiel, D.R. To include or not to include (the invader in community analyses)? That is the question. Biol. Invasions 2016, 18, 1515-1521. [CrossRef]

85. Klein, J.C.; Verlaque, M. Experimental removal of the invasive Caulerpa racemosa triggers partial assemblage recovery. J. Mar. Biol. Assoc. UK 2011, 91, 117-125. [CrossRef]

86. Staehr, P.A.; Pedersen, M.F.; Thomsen, M.S.; Wernberg, T.; Krause-Jensen, D. Invasion of Sargassum muticum in Limfjorden (Denmark) and its possible impact on the indigenous macroalgal community. Mar. Ecol. Prog. Ser. 2000, 207, 79-88. [CrossRef]

87. Forrest, B.M.; Taylor, M.D. Assessing invasion impact: Survey design considerations and implications for management of an invasive marine plant. Biol. Invasions 2003, 4, 375-386.

88. Connor, E.F.; McCoy, E.D. The statistics and biology of the species-area relationship. Am. Nat. 1979, 113, 791-833. [CrossRef]

89. Clarke, K.; Gorley, R. Getting started with PRIMER v7. In PRIMER-E: Plymouth; Plymouth Marine Laboratory: Devon, UK, 2015.

90. Unistat, L. Unistat Version 5.5; Unistat: London, UK, 2002. 
91. Pitts, A. Polinode: A web application for the collection and analysis of network data. In Proceedings of the 2016 IEEE/ACM International Conference on Advances in Social Networks Analysis and Mining, San Francisco, CA, USA, 18-21 August 2016; pp. 1422-1425.

92. Paine, R.T. A note on trophic compelxity and community stability. Am. Nat. 1969, 103, 91-93. [CrossRef]

93. Schiel, D.R. Rivets or bolts? When single species count in the function of temperate rocky reef communities. J. Exp. Mar. Biol. Ecol. 2006, 338, 233-252. [CrossRef]

94. Memmott, J.; Waser, N.M. Integration of alien plants into a native flower-pollinator visitation web. Proc. R. Soc. Lond. B Biol. Sci. 2002, 269, 2395-2399. [CrossRef] [PubMed]

95. Donatti, C.I.; Guimarães, P.R.; Galetti, M.; Pizo, M.A.; Marquitti, F.M.; Dirzo, R. Analysis of a hyper-diverse seed dispersal network: Modularity and underlying mechanisms. Ecol. Lett. 2011, 14, 773-781. [CrossRef] [PubMed]

96. Olesen, J.M.; Bascompte, J.; Elberling, H.; Jordano, P. Temporal dynamics in a pollination network. Ecology 2008, 89, 1573-1582. [CrossRef] [PubMed]

97. Wahl, M.; Mark, O. The predominantly facultative nature of epibiosis: Experimental and observational evidence. Mar. Ecol. Prog. Ser. 1999, 187, 59-66. [CrossRef]

98. Thompson, J.N. Specific hypotheses on the geographic mosaic of coevolution. Am. Nat. 1999, 153, S1-S14. [CrossRef]

99. Thompson, J.N.; Cunningham, B.M. Geographic structure and dynamics of coevolutionary selection. Nature 2002, 417, 735. [CrossRef] [PubMed]

100. Siciliano, A. Testing When and How Habitat Cascades Control Biodiversity of Marine Benthic Ecosystems. Ph.D. Thesis, University of Canterbury, Christchurch, New Zealand, 2018.

101. South, P.M.; Floerl, O.; Forrest, B.M.; Thomsen, M.S. A review of three decades of research on the invasive kelp Undaria pinnatifida in Australasia: An assessment of its success, impacts and status as one of the world's worst invaders. Mar. Environ. Res. 2017, 131, 131-243. [CrossRef]

102. Kiirikki, M. Experimental evidence that Fucus vesiculosus (Phaeophyta) controls filamentous algae by means of the whiplash effect. Eur. J. Phycol. 1996, 31, 61-66. [CrossRef]

103. Reeves, S.; Kriegisch, N.; Johnson, C.; Ling, S. Reduced resistance to sediment-trapping turfs with decline of native kelp and establishment of an exotic kelp. Oecologia 2018, 188, 1239-1251. [CrossRef]

104. da Gama, B.A.P.; Plouguerné, E.; Pereira, R.C. Chapter Fourteen-The Antifouling Defence Mechanisms of Marine Macroalgae. In Advances in Botanical Research; Bourgougnon, N., Ed.; Academic Press: Cambridge, MA, USA, 2014; pp. 413-440.

105. Buchanan, J.; Zuccarello, G.C. Utility of molecular-assisted alpha taxonomy of the genus Cystophora (Fucales, Phaeophyceae) from New Zealand and Australia. Phycologia 2018, 57, 374-384. [CrossRef]

106. Adams, N.M. Seaweeds of New Zealand; Canterbury University Press: Canterbury, New Zealand, 1994.

107. South, P.M.; Lilley, S.A.; Tait, L.W.; Alestra, T.; Hickford, M.J.; Thomsen, M.S.; Schiel, D.R. Transient effects of an invasive kelp on the community structure and primary productivity of an intertidal assemblage. Mar. Freshw. Res. 2016, 67, 103-112. [CrossRef]

108. Epstein, G.; Smale, D.A. Undaria pinnatifida: A case study to highlight challenges in marine invasion ecology and management. Ecol. Evol. 2017, 7, 8624-8642. [CrossRef] [PubMed]

109. Thomsen, M.S.; Alestra, T.; Brockerhoff, D.; Lilley, S.A.; South, P.M.; Schiel, D.R. Modified kelp seasonality and invertebrate diversity where an invasive kelp co-occurs with native mussels. Mar. Biol. 2018, 165, 173. [CrossRef]

110. Simpson, R.; Smith, S.; Pople, A. The effects of a spillage of diesel fuel on a rocky shore in the sub-Antarctic region (Macquarie Island). Mar. Pollut. Bull. 1995, 31, 367-371. [CrossRef]

111. Fraser, C.I.; Nikula, R.; Waters, J.M. Oceanic rafting by a coastal community. Proc. R. Soc. B Biol. Sci. 2011, 278, 649-655. [CrossRef]

112. Anderson, M.J.; Diebel, C.E.; Blom, W.M.; Landers, T.J. Consistency and variation in kelp holdfast assemblages: Spatial patterns of biodiversity for the major phyla at different taxonomic resolutions. J. Exp. Mar. Biol. Ecol. 2005, 320, 35-56. [CrossRef]

113. Connell, S.; Foster, M.; Airoldi, L. What are algal turfs? Towards a better description of turfs. Mar. Ecol. Prog. Ser. 2014, 495, 299-307. [CrossRef]

114. Kelaher, B.; Chapman, M.; Underwood, A. Spatial patterns of diverse macrofaunal assemblages in coralline turf and their associations with environmental variables. J. Mar. Biol. Assoc. UK 2001, 81, 917-930. [CrossRef] 
115. Stewart, J.G. Anchor species and epiphytes in intertidal algal turf. Pac. Sci. 1982, 36, 45-59.

116. Liuzzi, M.G.; Gappa, J.L. Macrofaunal assemblages associated with coralline turf: Species turnover and changes in structure at different spatial scales. Mar. Ecol. Prog. Ser. 2008, 363, 147-156. [CrossRef]

117. Kelaher, B.P. Influence of physical characteristics of coralline turf on associated macrofaunal assemblages. Mar. Ecol. Prog. Ser. 2002, 232, 141-148. [CrossRef]

118. Flukes, E.; Johnson, C.; Wright, J. Thinning of kelp canopy modifies understory assemblages: The importance of canopy density. Mar. Ecol. Prog. Ser. 2014, 514, 57-70. [CrossRef]

119. Wernberg, T.; Connell, S.D. Physical disturbance and subtidal habitat structure on open rocky coasts: Effects of wave exposure, extent and intensity. J. Sea Res. 2008, 59, 237-248. [CrossRef]

120. Dayton, P.K.; Currie, V.; Gerrodette, T.; Keller, B.D.; Rosenthal, R.; Tresca, D.V. Patch dynamics and stability of some California kelp communities. Ecol. Monogr. 1984, 54, 253-289. [CrossRef]

121. Erlandsson, J.; Kostylev, V.; Williams, G.A. A field technique for estimating the influence of surface complexity on movement tortuosity in the tropical limpet cellana grata gould. Ophelia 1999, 50, 215-224. [CrossRef]

122. Little, C. Factors governing patterns of foraging activity in littoral marine herbivorous molluscs. J. Molluscan Stud. 1989, 55, 273-284. [CrossRef]

123. Taylor, D.I.; Schiel, D.R. Algal populations controlled by fish herbivory across a wave exposure gradient on southern temperate shores. Ecology 2010, 91, 201-211. [CrossRef]

124. Steneck, R.S. A limpet-coralline alga association: Adaptations and defenses between a selective herbivore and its prey. Ecology 1982, 63, 507-522. [CrossRef]

125. Airoldi, L.; Ballesteros, E.; Buonuomo, R.; Van Belzen, J.; Bouma, T.; Cebrian, E.; De Clerk, O.; Engelen, A.; Ferrario, F.; Fraschetti, S. Marine forests at risk: Solutions to halt the loss and promote the recovery of Mediterranean canopy-forming seaweeds. In Proceedings of the 5th Mediterranean Symposium on Marine Vegetation, Portorož, Slovenia, 27-28 October 2014.

126. Cecchi, L.B.; Cinelli, F. Canopy removal experiments in Cystoseira-dominated rockpools from the Western coast of the Mediterranean (Ligurian Sea). J. Exp. Mar. Biol. Ecol. 1992, 155, 69-83. [CrossRef]

127. Bulleri, F.; Cucco, A.; Dal Bello, M.; Maggi, E.; Ravaglioli, C.; Benedetti-Cecchi, L. The role of wave-exposure and human impacts in regulating the distribution of alternative habitats on NW Mediterranean rocky reefs. Estuar. Coast. Shelf Sci. 2018, 201, 114-122. [CrossRef]

128. Mangialajo, L.; Chiantore, M.; Cattaneo-Vietti, R. Loss of fucoid algae along a gradient of urbanisation, and structure of benthic assemblages. Mar. Ecol. Prog. Ser. 2008, 358, 63-74. [CrossRef]

129. Wernberg, T.; Tuya, F.; Thomsen, M.S.; Kendrick, G.A. Turban snails as habitat for foliose algae: Contrasting geographical patterns in species richness. Mar. Freshw. Res. 2010, 61, 1237-1242. [CrossRef]

130. Thyrring, J.; Thomsen, M.S.; Wernberg, T. Large-scale facilitation of a sessile community by an invasive habitat-forming snail. Helgol. Mar. Res. 2013, 67, 789. [CrossRef]

131. Gutiérrez, J.L.; Jones, C.G.; Strayer, D.L.; Iribarne, O.O. Mollusks as ecosystem engineers: The role of shell production in aquatic habitats. Oikos 2003, 101, 79-90. [CrossRef]

132. Altieri, A.H.; Witman, J.D. Modular mobile foundation species as reservoirs of biodiversity. Ecosphere 2014, 5, 1-11. [CrossRef]

133. Ducker, S.C.; Leblanc, J.; Johansen, H.W. An epiphytic species of Jania (Corallinaceae: Rhodophyta) endemic to southern Australia. Contrib. Herb. Aust. 1976, 17, 1-8.

134. Gutiérrez, J.L.; Palomo, M.G. Increased algal fouling on mussels with barnacle epibionts: A fouling cascade. J. Sea Res. 2016, 112, 49-54. [CrossRef]

135. Smale, D.A.; Wernberg, T. Extreme climatic event drives range contraction of a habitat-forming species. Proc. R. Soc. B Biol. Sci. 2013, 280, 20122829. [CrossRef]

136. Smale, D.A.; Wernberg, T.; Oliver, E.C.J.; Thomsen, M.; Harvey, B.P.; Straub, S.C.; Burrows, M.T.; Alexander, L.V.; Benthuysen, J.A.; Donat, M.G.; et al. Marine heatwaves threaten global biodiversity and the provision of ecosystem services. Nat. Clim. Chang. 2019, 9, 306-312. [CrossRef]

137. Hargrove, W.W.; Pickering, J. Pseudoreplication: A sine qua non for regional ecology. Landsc. Ecol. 1992, 6, 251-258. [CrossRef]

138. Fraser, C.I.; Winter, D.J.; Spencer, H.G.; Waters, J.M. Multigene phylogeny of the southern bull-kelp genus Durvillaea (Phaeophyceae: Fucales). Mol. Phylogenetics Evol. 2010, 57, 1301-1311. [CrossRef] [PubMed] 
139. Fraser, C.I.; Hay, C.H.; Spencer, H.G.; Waters, J.M. Genetic and morphological analyses of the southern bull kelp Durvillaea antarctica (Phaeophyceae: Durvilleales) in New Zealand reveal cryptic species. J. Phycol. 2009, 45, 436-443. [CrossRef] [PubMed]

140. Schiel, D.R.; Steinbeck, J.R.; Foster, M.S. Ten years of induced ocean warming causes comprehensive changes in marine benthic communities. Ecology 2004, 85, 1833-1839. [CrossRef]

141. Alestra, T.; Schiel, D.R. Non-trophic responses of algal communities to nutrient enrichment: Interactions among coralline turfs, ephemeral algae and perennial fucoids. Mar. Ecol. Prog. Ser. 2015, 538, 145-156. [CrossRef]

142. Gutiérrez, J.L.; Bagur, M.; Palomo, M.G. Algal Epibionts as Co-Engineers in Mussel Beds: Effects on Abiotic Conditions and Mobile Interstitial Invertebrates. Diversity 2019, 11, 17. [CrossRef]

143. Zhang, Y.S.; Silliman, B.R. A Facilitation Cascade Enhances Local Biodiversity in Seagrass Beds. Diversity 2019, 11, 30. [CrossRef]

144. Thornber, C.; Jones, E.; Thomsen, M. Epibiont-marine macrophyte assemblages. In Marine Macrophytes As Foundation Species; CRC Press: Boca Raton, FL, USA, 2016; pp. 43-65.

145. Zotz, G.; Hietz, P. The physiological ecology of vascular epiphytes: Current knowledge, open questions. J. Exp. Bot. 2001, 52, 2067-2078. [CrossRef]

(C) 2019 by the authors. Licensee MDPI, Basel, Switzerland. This article is an open access article distributed under the terms and conditions of the Creative Commons Attribution (CC BY) license (http:// creativecommons.org/licenses/by/4.0/). 